\title{
Świadectwo, wyznanie, wyzwanie - dla pedagogii? 0 doświadczeniach formacyjnych Jerzego Stempowskiego, Józefa Czapskiego i Czesława Miłosza
}

Streszczenie: Autorka artykułu, odwołując się do „autobiograficznego trójkąta” propozycji badawczej Małgorzaty Czermińskiej, poszukuje w literaturze dokumentu osobistego świadectw edukacyjnych. Utrwalone w zapisach autobiograficznych doświadczenia formacyjne Jerzego Stempowskiego, Józefa Czapskiego i Czesława Miłosza traktowane są jako świadomie pozostawione przed sobą wyzwanie. Rekonstrukcja sytuacji pedagogicznych utrwalonych przez nich samych, zarówno jako twórców, jak i pedagogów, stanowi propozycję krytycznego namysłu nad współczesnością.

Słowa klucze: biografia kulturalna, literatura dokumentu osobistego, edukacja kulturalna, formacja kulturalna.

\section{Certificate, religion, a challenge for pedagogy? \\ The formative experiences of Jerzy Stempowski, Józef Czapski and Czesław Miłosz}

Summary: Małgorzata Czermińska's concept of the autobiographic triangle augments the range of categories already established in the studies of literature of the personal document, namely those of testimony and confession, with a new, third category - that of a challenge. This new category releases the reading of literature of the personal document from the ancillary supportive role in both understanding of a specific creative attitude and a fuller understanding of the literary work proper, awards it with a more extensive autonomy. Dorota Sieroń-Galusek decided to fol-

* Uniwersytet Śląski, Wydział Etnologii i Nauk o Edukacji, Zakład Edukacji Kulturalnej, 40-007 Katowice, ul. Bankowa 12. 
low this options in the above study of cultural biography of Jerzy Stempowski, Józef Czapski and Czesław Miłosz in search for the most important pedagogical situations shaping a personality capable of living creatively in changing conditions.

Keywords: cultural biography, literature of personal testimony, cultural education, cultural formation.

Małgorzata Czermińska w pracy Autobiograficzny trójkąt. Świadectwo, wyznanie $i$ wyzwanie na użytek badań nad literaturą dokumentu osobistego wprowadza kategorie „świadectwa”, „wyznania” i „wyzwania”, określając tym samym typy narracji w pisarstwie autobiograficznym. Postawa świadka, czyli tego, kto bezpośrednio uczestniczy w zdarzeniu i relacjonuje je, oraz postawa wyznającego - dokonującego wglądu w siebie i oglądu siebie jako podmiotu doświadczającego, są według badaczki postawami powszechnie przyjętymi wśród badaczy literatury dokumentu osobistego ${ }^{1}$. W prowadzona przez Czermińską nowa kategoria „wyzwania” uświadamia celowość opisu siebie i świata w biografistyce. Tym samym to, co osobiste, zyskuje wymiar powszechniejszy i to zgodnie z intencją wyznającego. Autorka stwierdza: „Ten typ autobiograficznej postawy, sytuuje się poza linią przebiegającą w obrębie pierwotnej dychotomii świadectwa i wyznania, pojawił się w polskiej literaturze dokumentu osobistego zaledwie pół wieku temu. Jeśli utajony dawniej trzeci biegun wyobrazimy sobie jako punkt usytuowany ponad lub poniżej linii przebiegającej między biegunami ekstrawersji (postawą świadectwa) i introwersji (postawą wyznania), otrzymamy trójkąt autobiograficz$n y$. Na pierwszym wierzchołku sytuuje się ja mówiącego, na drugim - świat zewnętrzny przedstawiony w zapisie autobiograficznym, a na trzecim - czytelnik" (Czermińska, 2000, s. 23). Jak przekonuje badaczka zapis autobiograficzny staje się niejako wyzwaniem rzuconym przez piszącego czytelnikowi.

Ta propozycja teoretyczna otwiera przed nami szerokie pole eksploracji badawczej literatury dokumentu osobistego. Wszak wyzwanie rzucone przez autora kierowane jest do czytelnika, którym niekoniecznie musi być literaturoznawca. Przyjęcie autobiograficznego trójkąta sprawia, że literatura dokumentu osobistego przestaje być wyłącznie pomocna w badaniach wspierających w rozumieniu postawy twórczej, nie służy tylko pełniejszemu zrozumieniu dzieła właściwego, jakim jest twórczość poetycka czy prozatorska. Świadectwo czy wyznanie, które w zamyśle piszącego jest wyzwaniem skierowanym ku odbiorcy, sprawia, że literatura dokumentu osobistego zyskuje niejako większą autonomię, stając się cennym źródłem nie tylko w badaniach historyczno-literackich. Wszak w listach, dziennikach, wspomnieniach, rozmowach odnajdujemy między innymi świadectwo tego, jak przebiegała formacja kulturalna twórcy. Ich autorzy wyznają czytelnikowi nie tylko to, co bezpośrednio dotyczy ich twórczości, ale i możemy się

${ }^{1}$ Literatura dokumentu osobistego obejmuje gatunki prozy niefikcjonalnej: dziennik, wspomnienie, list, autobiografia, esej, rozmowa, wywiad. 
dowiedzieć, jakie miejsca i sytuacje ich kształtowały, jakie osoby wspierały ich w rozwoju osobowym i twórczym.

Wręcz moglibyśmy zapytać, dlaczego twórcy uznani, spełniający się w określonej dziedzinie sztuki, na przykład poezji czy malarstwie, pozostawili w listach, dziennikach, wspomnieniach tak liczne zapisy ich doświadczeń formacyjnych. Dlaczego Czesław Miłosz - którego życiowym powołaniem było stać się poetą, czy Józef Czapski - twórca spełniający się w malarstwie, dlaczego ci artyści tak często w literaturze dokumentu osobistego, powracając do sytuacji pedagogicznych, opisują siebie jako uczniów, jako twórców nieustających w pracy nad samodoskonaleniem się, ale i opisują siebie jako nauczycieli dzielących się zarówno swoją wiedzą, jak i doświadczeniem życiowym.

W dalszej części rozważań, podejmując to pytanie, chciałabym również przywołać Jerzego Stempowskiego - eseistę, o którym Czesław Miłosz mówił tak: „Ponieważ nie znaleźlibyśmy nikogo innego, kto wypowiada się tylko i wyłącznie w eseju, jest jedynym polskim eseistą" (Miłosz, 1961, s. 42). Patrząc na dorobek literacki Stempowskiego z dzisiejszej perspektywy, należałoby do tej spuścizny dodać liczną korespondencję ${ }^{2}$. Oba jednak gatunki, esej (Wyka, 2006, s. 427) i list, należą do polskiej biografistyki. W twórczości niespiesznego przechodnia ${ }^{3}$ zyskujemy przykład świadomie i konsekwentnie obranej drogi tworzenia literatury dokumentu osobistego. Taki wybór zdaje się podkreślać wartość wskazanej przez Czermińską kategorii wyzwania jako charakterystycznej dla biografistyki zainicjowanej w drugiej połowie XX w.

Przyjmując założenia autorki Autobiograficznego trójkąta rozważmy, jakie możliwości daje nam włączenie literatury dokumentu osobistego do badań nad biografią edukacyjną uznanych twórców kultury?

${ }^{2}$ Na opublikowaną twórczość Jerzego Stempowskiego składają się obok esejów: Chimera jako zwierze pociagowe 1926-1941, wybór i opracowanie J. Timoszewicz, Czytelnik, Warszawa 2001; Eseje dla Kassandry, Biblioteka Mnemosyne, red. Piotr Kłoczowski, słowo/obraz terytoria, Gdańsk 2005; Eseje, wybór i wstęp W. Karpiński, Znak, Kraków 1984; Od Berdyczowa do Lafitów, wybór i opracowanie A. S. Kowalczyk, Wydawnictwo Czarne, Wołowiec 2001; Pamiętnik teatralny trzeciej klasy, wybór i opracowanie J. Timoszewicz, Wydawnictwo Literackie, Kraków 1999; $W$ dolinie Dniestru i inne eseje ukraińskie, wybór, opracowanie A. S. Kowalczyk, LNB, Warszawa b.d.w.; Ziemia berneńska, przełożył i posłowiem opatrzył A. S. Kowalczyk, Czytelnik, Warszawa 1990; dziennik: Zapiski dla zjawy, tłumaczenie i posłowie Jan Zieliński, Noir sur blanc, Warszawa 2004, oraz liczna korespondencja: M. Dąbrowska, J. Stempowski, Listy, Tom I, 1926-1953, Tom II, 1954-1958, Tom III, 1959-1965, opracował, wstępem opatrzył A. S. Kowalczyk, Biblioteka „Więzi”, Warszawa 2010; J. Giedroyć, J. Stempowski, Listy 1946-1969, część 1, 2, wybór i opracowanie A. S. Kowalczyk, Czytelnik, Warszawa 1998; B. Miciński, J. Stempowski, Listy, LNB, Warszawa 1995; J. Stempowski, Listy do różnych adresatów, wybór i red. B. Toruńczyk, Zeszyty Literackie, Warszawa 2000; J. Stempowski, Listy z ziemi berneńskiej, do druku przygotowała L. Ciołkowska, Oficyna Poetów i Malarzy, Londyn 1974.

${ }^{3}$ Określenie używane przez badaczy w odniesieniu do Jerzego Stempowskiego (patrz: Kowalczyk, 1997) W latach 1954-1969 Jerzy Stempowski publikował w paryskiej „Kulturze” szkice w rubryce „Notatnik niespiesznego przechodnia”. 
Wybrani twórcy: Stempowski, Czapski, Miłosz tworzyli środowisko skupione wokół czasopisma „Kultura”. Żyli oni na tyle długo, że możemy prześledzić wszystkie fazy ich życia: od dzieciństwa, poprzez dojrzałość po starość. W ich los wpisała się „sytuacja ciągłej zmiany” - zmiana statusu społecznego, utrata rodzinnych majątków, emigracja i możliwość powrotu do kraju. Biografie tych twórców zakreślają nam szeroką perspektywę czasową: od 1893 (kiedy rodzi się Stempowski) po 2004 r. (kiedy umiera Miłosz). Ich doświadczenia edukacyjne (zarówno ich edukacja, jak i edukowanie innych) obejmują rozmaite okresy: zaborów; Polski niepodległej, gdzie tworzono szkolnictwo narodowe; czas wojny i tajne nauczanie; lata powojenne, które z uwagi na emigrację otworzyły przed nimi perspektywę wglądu w dwa modele edukacji systemowej: państw bloku komunistycznego i państw demokratycznych. Ponadto doświadczenie życiowe Miłosza to sposobność porównania edukacji w Europie i Ameryce. (W ich doświadczeniu zyskujmy perspektywę długiego trwania jakże istotną w badaniach nad historią kulturową (Burke, 2012), która może się również okazać inspirująca w badaniach pedagogicznych). Oni sami na przestrzeni lat zyskiwali sposobność krytycznego oglądu swoich doświadczeń. Być może ta ich potrzeba zapisu doświadczenia pedagogicznego wynikała właśnie z obserwacji zmian, jakie dostrzegali w swoim długim życiu. Być może mając sposobność porównania systemów szkolnictwa w różnych ustrojach politycznych, tym wyraźniej jawiły im się wartości konstytutywne dla sytuacji pedagogicznej, w której zdobywa formację osoba w pełni autonomiczna, potrafiąca samodzielnie wartościować i dokonywać autonomicznych wyborów.

Ich spuścizna literacka obejmuje obszerną literaturę dokumentu osobistego, co daje nam wgląd nie tylko w ich życie (pozwala prześledzić koleje losu), ale przede wszystkim pozwala nam poznać ich myśli i opinie. Możemy z niej wyśledzić ważne relacje międzyludzkie i hierarchie ludzi znaczących w ich życiu. A także przyjrzeć się miejscom i sytuacjom, w których ta formacja się dokonywała. Zważywszy na konsekwentne przywoływanie przez nich osób znaczących $\mathrm{w}$ ich formacji kulturalnej, można wręcz jako postulat określający proponowaną przez nich postawę pedagogiczną przyjąć słowa Czesława Miłosza wygłoszone w Królewskiej Akademii Szwedzkiej, kiedy podczas uroczystości przyznania Nagrody Nobla poeta mówił: „Wydaje mi się, że powinniśmy publicznie oświadczyć o naszym przywiązaniu do pewnych nazwisk, bo w ten sposób jaśniej określamy naszą pozycję, niż wymieniając nazwiska, którym przeciwstawiamy się gwałtownie" (Miłosz, 2006, s. 491).

Wypowiedzi utrwalone czy to w liście, wspomnieniu, dzienniku czy eseju mają charakter osobisty i nie są wolne od subiektywnego postrzegania świata. Celem badań porównawczych biografii edukacyjnych twórców kultury nie jest jednak weryfikacja zgodności podawanych przez autorów faktów z rzeczywistością. A zatem nie jest tu ważne umieszczenie ich doświadczeń formacyjnych na tle epoki. Mając na uwadze prowadzone już od lat studia nad biografią po- 
szczególnych artystów, nie wydaje się bowiem, aby takie badania stanowić mogły znaczący głos. Taka rekonstrukcja nie przesądza również o stanie badań nad historią edukacji. Ważne jest raczej potraktowanie tej spuścizny literackiej zgodnie z zaproponowaną przez Małgorzatę Czermińską kategorią „wyzwania”, jakie piszący kieruje do odbiorcy (zarówno czytelników, jak i badaczy). Tym samym rekonstrukcja opisanych przez artystów sytuacji pedagogicznych jest dla nas sposobnością dotarcia do tego, co stanowi kwintesencję relacji nauczyciel-uczeń, co nazwać by można gramatyką tej relacji.

Czytając pozostawioną przez Stempowskiego, Czapskiego, Miłosza obszerną literaturę dokumentu osobistego, nie możemy uciec od pytania, dlaczego tak często podejmują oni temat pedagogii? Stanowi ona przedmiot rozważań w esejach, wspomnieniach, dzienniku i jakże często jest podejmowana przez nich w rozmowie korespondencyjnej.

Dla dzisiejszego czytelnika intrygujące jest to, że utrwalone przez nich doświadczenia i przemyślenia odbiegają od tego, co obecnie jest preferowane w kulturze i edukacji. W miejsce obowiązującego dziś profesjonalizmu wskazują nam oni raczej ciągłą niepewność oraz poszukiwanie metod i sposobów pracy z uczniem. Zamiast przekonywania nas o konieczności zdobywania umiejętności praktycznych i przydatnych z perspektywy dnia dzisiejszego, podkreślają raczej bezinteresowność w zdobywaniu wiedzy i jej pozorny wymiar bezużyteczny, który z czasem okazuje się umiejętnością niezwykle przydatną i oczekiwaną.

I może dlatego, że z literatury dokumentu osobistego pozostawionej przez tych wybitnych twórców wyłania nam się dość idealistyczny model sytuacji pedagogicznej, jest on wart prześledzenia. Bo czyż rekonstrukcja ich ścieżki edukacyjnej nie jest dobrym punktem wyjścia do podjęcia dyskusji o formacji kulturalnej człowieka współczesnego?

Żaden z nich, zapewne świadom złożoności i wieloaspektowości sytuacji pedagogicznej, najprawdopodobniej nie podjąłby się tworzenia modelu edukacji kulturalnej. I przyjmując za słuszne takie założenie, być może nie powinniśmy również podejmować tego typu prób w badaniach biografii edukacyjnych artystów.

W literackich świadectwach Stempowskiego, Czapskiego, Miłosza możemy jednak zaobserwować podobieństwa doświadczeń pedagogicznych. Bez wątpienia jest nim „moment osobisty” (jak to określił Józef Czapski), czyli osobowe zaangażowanie się uczestników sytuacji pedagogicznej zarówno wychowawcy, jak i wychowanka. W utrwalonym zapisie możemy przyjrzeć się temu, jak oni sami, jako uczniowie, bezinteresownie angażują się w sytuacje pedagogiczne, a później, edukując innych, nie rezygnują z waloru osobowościowego, jaki wnoszą, będąc już nauczycielami i budując swoje relację z uczniem. Jerzego Stempowskiego ukształtowała stworzona przez jego rodziców Akademia Winikowiecka. Zdobywając formację w tej domowej szkole, w której nie było wyraźnych podziałów na wykładowców i słuchaczy (wykładały w niej zarówno dzieci, jak i rodzice), uczył się bezinteresowności i odpowiedzialności. Choć nikt nie stawiał tam ocen 
za przygotowanie, wszyscy domownicy poczuwali się do tego, aby jak najlepiej zaprezentować materiał będący przedmiotem cotygodniowych studiów. Dla Czesława Miłosza, poety, a później też wykładowcy, bardzo ważnym doświadczeniem formacyjnym była aktywność w kołach samokształceniowych i naukowych w czasie licealnym oraz podczas studiów w Wilnie (Franaszek, 2011, s. 51-193, Zawada, 2004, s. 31-63).

Natomiast dla Józefa Czapskiego ważnym doświadczeniem formacyjnym była grupa kapistów, tworzona przez studentów malarstwa w krakowskiej Akademii Sztuk Pięknych, którzy kształcili się w pracowni Józefa Pankiewicza. Pod jego wpływem młodzi studenci wyruszyli do ówczesnej stolicy kulturalnej - Paryża. W 1923 r. zawiązali oni Komitet Paryski - organizację wspierającą studentów w wyjeździe na studia malarskie do Francji. W skrócie o organizacji mówiono K.P., co z czasem przylgnęło jako określenie kapiści, jakiego używa się na określenie uprawianej przez nich sztuki. To wśród przyjaciół malarzy, których prowadził rozważnie i z wyczuciem Pankiewicz, Czapski doświadczył, czym jest bycie w grupie opartej na wzajemnej życzliwości i zaufaniu, która wspiera się w samodoskonaleniu.

W formacji kulturalnej tej trójki twórców niezwykle ważną rolę odgrywała lektura, częstokroć była to wspólna rodzinna lektura bądź też lektura tych samych książek w kręgu przyjaciół. Zawsze wsparta rozmową.

Ich obycie w świecie kultury zaczynało się od poznania świata wokół, nabywania kompetencji opisywania bliskiej okolicy. Ta uruchomiona w dzieciństwie potrzeba poznania jako doświadczania (poprzez kontakt z miejscem czy osobą) stała się w późniejszych latach naturalnym sposobem ich uczestnictwa w kulturze. I to nieustające bezinteresowne zaangażowanie się w sprawy kultury sprawiało chyba, że potrafili oni z taką naturalnością włączać innych do uczestnictwa w kulturze.

Za Czesławem Miłoszem moglibyśmy ich określić jako gospodarzy kultury, dodając za Jerzym Stempowskim - gospodarzy, których cechowała niespieszność. Niespieszne, a zatem odbywające się w odpowiednim tempie, ale i nieuwarunkowane żadnym partykularnym celem było ich poznawanie i doświadczanie kultury. W tym procesie istotną rolę odegrali inni: rodzice, pedagodzy i przyjaciele. I świadomość tego sprawiała chyba, że czuli się oni odpowiedzialni, aby w ten sam sposób wprowadzać w kulturę innych, dokonując niejako powtórzenia tego doświadczenia w nowej roli.

W ich przypadku wejście w rolę wprowadzającego innych w świat kultury odbywało się poprzez ciągłą weryfikację swoich metod pracy. Każda sytuacja pedagogiczna traktowana była jako spotkanie stające się, a zatem wymagające od nauczyciela ciągłej uważności i otwartości na to, co wydarza się w sali wykładowej. Jeden ze studentów Czesława Miłosza tak wspominał poetę i wykładowcę: „Miał w sobie silne poczucie obowiązku i sumienności, które sprawiały, że cze- 
gokolwiek się podejmował, robił to dobrze i dokładnie. Książka, stanowiąca owoc jego wykładów - Historia literatury polskiej - to rodzaj cudu: podręcznik, który można czytać dla przyjemności. Lubił mały teatr sali wykładowej, ale nigdy nie pociągały go dramatyczne efekty; tym rysem powściągliwości naznaczony był zarówno jego sposób nauczania, jak też sposób, w jaki recytował swoją poezję [...]" (Lourie, 2012, s. 81).

Stempowski, Czapski, Miłosz byli dla swoich uczniów mistrzami rozmowy. Nie traktowali oni nauczania jako formy wykładania określonych treści, istotne było spotkanie we wspólnej rozmowie, a to wymagało ciągłej uwagi. Halina Micińska-Kenarowa tak wspominała Jerzego Stempowskiego: „Każda rozmowa z nim była zapładniająca, bo otwierała nieoczekiwane perspektywy i mało znane horyzonty, a sztukę rozmowy uprawiał z całą świadomością, osiągając arcydzieła kunsztu i finezji uwodzącej słuchacza poprzez pięknie zarysowane meandry ku niespodziewanym wnioskom" (Micińska-Kenarowa,1995, s. 15). W książce Józef Czapski. Tumult i olśnienia, która jest właściwie relacją ucznia ze spotkań z mistrzem odbywających się w małym pokoju domu „Kultury” w Maisons-Laffitte, Jil Silberstein tak scharakteryzował rozmowy z malarzem: „Cokolwiek byście powiedzieli nie przechodziło niezauważone. Najskromniejsze zdanie z miejsca wywoływało entuzjazm («bardzo dobrze»), zaskoczenie, oburzenie, protest, wesołość, nieskoordynowane ruchy długiego ciała, dygresje, wspomnienia lub wyznania «Wie pan ...MUSZĘ coś panu powiedzieć»" (Silberstein, 2004, s. 19). Krystyna Zachwatowicz (Zachwatowicz-Wajda, 1996) wręcz mówi o darze uwagi i życzliwości, jakim obdarowywał Czapski swoich rozmówców.

Świadomie podjęte przez tę trójkę twórców powtórzenie sytuacji pedagogicznych polegało również na konfrontacji z antywzorem. Doświadczenie negatywne nie musi być wykluczające w procesie samorozwoju. Stempowski, Czapski i Miłosz przekonują raczej, że umiejętność wskazania dwóch skrajnych postaw (wzoru i antywzoru) otwiera perspektywę twórczej kreacji zarówno dla osoby poznającej kulturę, jak i uczącej innych.

W przypadku tej trójki mamy do czynienia z mistrzami myślenia osobnego, wszak ich postawa nie była podporządkowana panującym modom intelektualnym czy światopoglądowym. Żyjąc w świecie podlegającym zmianie (społecznej, politycznej, gospodarczej, cywilizacyjnej), byli z jednej strony otwarci na nowe (nowe miejsca, ludzie, idee), a przy tym konsekwentni w realizacji określonych wartości, co w różnych momentach musiało czynić z nich osoby nieprzystające do oczekiwań zgłaszanych przez większość, a zarazem chyba utwierdzało w wyborze drogi myślenia osobnego.

Stempowski, Czapski, Miłosz należą dziś do kanonu polskiej kultury, dlatego te pozostawione przez nich zapisy doświadczeń formacyjnych warto potraktować jako ważne dziedzictwo, być może z rozmysłem pozostawione przez tych wybitnych twórców i cenionych pedagogów, o których uczniowie z wdzięcznością mówią - mistrzowie. 


\section{Literatura}

Burke P., 2012, Historia kulturowa. Wprowadzenie, thum. J. Hunia, Wydawnictwo Uniwersytetu Jagiellońskiego, Kraków.

Czermińska M., 2000, Autobiograficzny trójkąt. Świadectwo, wyznanie i wyzwanie, Universitas, Kraków.

Dąbrowska M., Stempowski J., 2010, Listy, Tom I, 1926-1953; Tom II, 1954-1958; Tom III, 19591965, oprac., wstępem opatrzył A. S. Kowalczyk, Biblioteka „Więzi”, Warszawa.

Franaszek A., 2011, Miłosz. Biografia, Wydawnictwo Znak, Kraków.

Giedroyć J., Stempowski J., 1998, Listy 1946-1969, część 1, 2, wyb. i oprac. A. S. Kowalczyk, Czytelnik, Warszawa.

Kowalczyk A. S., 1997, Nieśpieszny przechodzień i paradoksy, Towarzystwo Przyjaciół Polonistyki Wrocławskiej, Wrocław.

Lourie R., 2012, Miłość od ostatniego wejrzenia, „Zeszyty Literackie”, nr 4 (120).

Miciński B., Stempowski J., 1995, Listy, LNB, Warszawa.

Micińska-Kenarowa, 1995, O Jerzym Stempowskim 1983-1969, [w:] B. Miciński, J. Stempowski, Listy, LNB, Warszawa.

Miłosz Cz., 2006, Królewska Akademia Szwedzka, Sztokholm, grudzień 1980, [w:] idem, Zaczynając od moich ulic, Wydawnictwo Znak, Kraków, s. 491.

Miłosz Cz., 1961, Proza, „Kultura”, nr 11.

Silberstein J., 2004, Józef Czapski. Tumult i olśnienia, Noir sur Blanc, Warszawa.

Stempowski J., 2001, Chimera jako zwierze pociagowe 1926-1941, wyb. i oprac., J. Timoszewicz, Czytelnik, Warszawa.

Stempowski J., 2005, Eseje dla Kassandry, Biblioteka Mnemosyne pod red. P. Kłoczowskiego, słowo/obraz terytoria, Gdańsk.

Stempowski J., 1984, Eseje, wyb. i wstęp W. Karpiński, Znak, Kraków.

Stempowski J., 2001, Od Berdyczowa do Lafitów, wyb. i oprac. A. S. Kowalczyk, Wydawnictwo Czarne, Wołowiec.

Stempowski J., 1999, Pamiętnik teatralny trzeciej klasy, wyb. i oprac. J. Timoszewicz, Wydawnictwo Literackie, Kraków.

Stempowski J., b.d.w., $W$ dolinie Dniestru i inne eseje ukraińskie, wyb. i oprac. A. S. Kowalczyk, LNB, Warszawa

Stempowski J., 1990, Ziemia berneńska, przełożył i posłowiem opatrzył A. S. Kowalczyk, Czytelnik, Warszawa.

Stempowski J., 2004, Zapiski dla zjawy, thum. i posłowie J. Zieliński, Noir sur Blanc, Warszawa.

Stempowski J., 2000, Listy do różnych adresatów, wyb. i red. B. Toruńczyk, Zeszyty Literackie, Warszawa.

Stempowski J., 1974, Listy z ziemi berneńskiej, do druku przygotowała L. Ciołkowska, Oficyna Poetów i Malarzy, Londyn.

Wyka M., 2006, Esej jako autobiografia, [w:] eadem, Niecierpliwość krytyka. Recenzje i szkice z lat 1961-2005, Universitas, Kraków.

Zachwatowicz-Wajda K., Wnętrze. Józef Czapski w stulecie urodzin, Muzeum Narodowe w Krakowie, 03.04-19.05.1996, materiały broszurowe towarzyszące wystawie.

Zawada A., 2004, Miłosz, Wydawnictwo Dolnośląskie, Wrocław. 